\title{
Navigating Environmental Education Practices to Promote Environmental Awareness and Education
}

\author{
Eliseo P. Marpa \\ Philippine Normal University Visayas, Philippines, marpa.ep@pnu.edu.ph
}

\begin{abstract}
Inhabitants of Planet Earth are experiencing environmental tensions brought about by the different problems plaguing the environment prompting the researcher to conduct a study on navigating environmental education practices in promoting environmental awareness and education. To answer this problem, the researcher employed a quantitative-qualitative method of research using the modified survey questionnaire from Eriko Arai and Shauna Sprules and the developed interview guide for the selected participants. Findings show that the majority is integrating environmental education, and it is evident in sciences, social studies, and values education. Integration, in this regard, was done weekly. On the other hand, activities that helped students learn about sound environment practices were lecturing, hands-on outdoor learning, and field trips that encourage the planting of trees, recycling, greening schoolyards, etc. Findings also reflected that the majority of the teachers did not discuss the different perspectives of environmental issues. When they discussed, they did not encourage students to form their views and ideas on different environmental issues. However, teachers were all eager to integrate environmental education despite barriers such as curriculum materials and teachers' competencies. Along this line, the study suggests for the development of instructional materials and training for teachers in the teaching and integration of environmental education in the different subject areas.
\end{abstract}

Keywords: Education, Environmental awareness, Environmental education, Navigating, Practices

\section{Introduction}

All inhabitants of Planet Earth are experiencing environmental stress brought by harmful wastes coming into the various layers of the earth's biosphere. The Planet Earth is already giving us a sign of its dreaded state. Inhabitants are currently experiencing the results of climate change, and many other threats plaguing the environment. This experience is universal, and no other countries are exempted from these environmental threats and challenges (Memije-Cruz, 2010). Likewise, Rogan (2019) expressed that the earth is suffering from innumerable afflictions at present caused by egregious human activities that relentlessly denude the environment. In other words Planet Earth is not getting any younger anymore. It is experiencing sickness inflicted by humans. We are shortening its life span due to activities brought into her. The more we improve lives through industrialization, the more we destroy our environment. In return, the earth is giving back what we have given her through strong typhoons, flash floods, landslides, drought and other environmental phenomena which if becoming worse would end our stay on this planet.

In the global context, "the environment is under pressure from climatic variability and anthropogenic activities including deforestation, wetland and water catchment destruction, agro-chemicals use, and urbanization, among others. Rogayan and Nebrida (2019) contend that in today's era of globalization, we are faced with a lot of societal upheavals including dilemmas pertaining to the environment. These dilemmas in the environment are the results of inappropriate information, ignorance, and poverty, whose cross-pollination aggravates the vulnerability of the environment, threatening flora and fauna (Peter \& Cheruto, 2013).

The growing concern with environmental issues and their impact on general awareness is one of the most noticeable phenomena of the last two decades (Marques \& Xavier, 2020; Sivamoorthy, Nalini \& Satheesh Kumar, 2013 as cited in Rogaya, 2019). The rapid depletion of the earth's natural resources and the fast degrading environment are the realities which can no longer be denied. These are the grave scenarios that threaten the existence of both man and the earth (Marpa \& Juele, 2016).

UNESCO (1994) stressed that natural balance had been disrupted, and natural resources are exhausted. Likewise, environmental degradation has increased due to our unsustainable consumption practices, unchecked population growth, and social and economic inequality. Limusnero (2016) also cited that evidence of environment degradation in the form of soil erosion, poor waste management, water pollution, and many other 
problems can still be observed in many schools and also in the communities around the schools. These issues are expected to impact the natural resources and ecosystems of the country and the world in general (Asano, 1991).

Thus, it was conceived that natural resources are at high risk in the ecosystem unless preventive steps are put in place immediately (Steve \& Cooper, 1985). Settlement trends, goals, and changes resulting from industrialization, mechanization, and technological advances management and environmental conservation had become a challenge today due to the nature of the activities that people engage in. All over the world, free human action has influenced virtually every significant aspect of the planet's environment. We can not prevent natural and even human-made disasters; but, if we are diligent enough and are more concerned about our climate, we can minimize the damage it causes (Moses, 2004).

In addition, it is important that every person gains an understanding of the limitations of our natural resources. If this is not achieved, there may be degradation of the people and their culture (Huckle, 1991; Fien \&Trainer, 1993). Since then, most of us have recognized environmental issues, but only a few people understand and are aware of the importance of the environment. As indicated by Memije-Cruz (2013) as cited in Marpa and Juele (2016) students possess a satisfactory knowledge on environmental conservation which means that the teaching of environmental education (EE) is not yet the concern of the majority of the high schools. Similarly, Jambiya (2003) about environmental management around Lake Victoria, revealed that people's awareness of environmental problems is low despite the fact that many people have attended school. Likewise, Mtaita (2007) found that although EE is integrated into all subjects in the school curriculum as directed by the education policy, the teaching of EE is not being implemented effectively. This simply shows that it is difficult to persuade other people, especially the youth, to appreciate the value and value of the situation.

Along this line, UNESCO-UNEP (1994) proposed the need for new environmental attitudes, skills, expertise, understanding, and behaviors especially to the grade school pupils, high school students, and even students in the tertiary level. Educating the citizenry is the best way to help us cope with environmental problems and challenges facing as today. Kimaryo (2011) believed that the teaching of EE will help learners develop knowledge, skills and positive attitudes towards the environment from a very early stage. She added that as a result, education would develop environmentally concerned citizens because through environmental education they would developed knowledge skills, concern and positive attitudes towards the environment. In this regard Puri and Joshi (2017) cited that EE is a process aimed at developing a world population that is aware of and concerned about the total environment and its associated problems and which has the knowledge, attitudes, commitments and skills to work individually and collectively towards the solution of current problems and prevention of new ones.

Environmental education is, therefore, necessary to teach and learn. Teaching students to act for the environment is essential. Its aim is to develop an informed citizenry that is environmentally conscious and motivated to actively participate in managing and sustainable use of its environment. This led to the integration of EE into the formal curriculum at all levels. The underlying aim is enable pupils in schools to develop knowledge about their environment, and an awareness of environmental issues and problems so that they can take an active part in seeking and implementing solutions to the problems facing them in their environment (URT, 2009).

Considering contentions presented, it is clear that EE has been practiced in some schools in the different parts of the globe including the Philippines. Although EE has been included in the school curriculum as mandated by the Department of Education (DepEd), the Commission on Higher Education (CHED), and the Technical Education and Skills Development Authority (TESDA), in coordination with the Department of Environment and Natural Resources (DENR), the Department of Science and Technology (DOST) and other relevant agencies, in consultation with experts on the environment and the academe, lead the implementation of public education and awareness programs on environmental protection and conservation through collaborative interagency and multisectoral effort at all levels (RA 9512, 2008). However, the condition of the environment has not improved. Recent studies (Kimaryo, 2011; Marpa \& Juele, 2010; Lindhe, 1999; Jambiya, 2003; Mtaita, 2007) have found that the implementation of EE has not been successful. Evidence of environmental degradation in the form of poor waste management, water pollution and many other forms of environmental issues can still be observed in many schools and the nearby communities. It is therefore the desire of the researcher to examine EE practices to promote environmental awareness and education of public schools in the northern part of the province of Negros Occidental. 


\section{Objectives of the Study}

This study aims to navigate EE among public schools to promote environmental awareness and education. Specifically, the study aims to: (1) determine the integration of EE in the lesson; (2) identify subjects areas where EE is integrated and how often it was integrated in the lessons; (3) determine the different teaching activities used by the teacher to help students learn about the environment; (4) determine if teachers have discussions of the different perspectives of environmental issues during the integration of EE; (5) determine the integration of EE from the curriculum and the teachers' initiative; (6) identify obstacles in incorporating EE among public schools; and (7) determine environmental activities undertaken to promote environmental awareness and education.

\section{Method}

\section{Research Method}

The author used quantitative-qualitative research, the sequential explanatory model in general. This analysis is characterized by quantitative data collection and analysis accompanied by qualitative data collection and analysis (Creswell, 2008). In the quantitative phase, the following stages were undertaken: (a) revision of the adapted questionnaire to fit in the researcher's purpose; (b) subject the questionnaire to expert validation and reliability; (c) after establishing the validity and reliability, the researcher finalized the questionnaire and reproduced several copies for the target participants; (d) the questionnaires were gathered and the data were tabulated and analyzed based from the objectives of the study. The information gathered in here determined the EE practices of public school teachers.

Gay, Mills, and Airasian (2003) indicated that the findings of the quantitative study determine the type of data collected in the qualitative phase. In the qualitative phase, after which practices were determined, the researcher conducted a semi-structured interview to expose the public school teachers' point of view on the different EE practices in and outside of the classroom. However, before the conduct of the semi-structured interview, the researcher drafted first the qualitative questions based from participants' responses in the quantitative questionnaire. The questions included in semi interview focused on: (a) the integration of EE in the lesson and how often it is integrated; (b) how integration is being undertaken; (c) the activities used to help students learn about the environment; (d) the discussion of the different perspectives on EE; (e) encouraging students to form their views and ideas when discussing environmental problems and issues; (f) the issue on whether integration is from the curriculum or from teacher's initiatives $(\mathrm{g})$ the integration in the different subject areas; $(\mathrm{h})$ the barriers in the integration of environmental education; and (i) on teacher's involvement in the different subject areas.

After the conduct of the semi-structured interview, the researcher tabulated the responses of the participants to the different questions considered by the researcher to determine practices in the integration of EE. Responses of the participants were transcribed using Microsoft word transferred to Microsoft excel for sorting and structuring of the text. Codes were then determined and analyzed.

The aim of the sequential explanatory design is usually to use qualitative outcomes to help explain and interpret predominantly quantitative design findings. The study's initial quantitative process was used to classify individuals, along with some interesting features correlated with research questions. Using this design, four main stages were considered. Figure 1 below shows the schematic diagram illustrating the four main stages.

\begin{tabular}{|c|c|c|c|c|c|c|c|c|}
\hline $\begin{array}{l}\text { Quantitative } \\
\text { data } \\
\text { collection }\end{array}$ & $\Rightarrow$ & $\begin{array}{l}\text { Quantitative } \\
\text { data } \\
\text { analysis }\end{array}$ & & $\begin{array}{l}\text { Qualitative } \\
\text { data } \\
\text { collection }\end{array}$ & & $\begin{array}{l}\text { Qualitative } \\
\text { data } \\
\text { analysis }\end{array}$ & $\Rightarrow$ & $\begin{array}{l}\text { Qualitative } \\
\text { data } \\
\text { analysis }\end{array}$ \\
\hline
\end{tabular}

Figure 1. Schematic diagram representing the various stages of the design

\section{Participants of the Study}

The participants of the study were the 743, public school teachers in the DepEd. They were determined using total enumeration, which means that the whole population of public school teachers in the school's division of Cadiz City was included as actual participants of the study. These participants were utilized to determine public 
school teachers' practices in the integration of EE in the classroom and in school. On the other hand, only 63 of the 743 participants in the semi-structured interview were selected to represent the four school districts in the elementary level and five to represent the high school level. Only subject coordinators of the four school districts and five nationalized high schools were considered. There are seven major subject areas were considered in this study and they are presented in Table 2 of the results and discussion. So there are 28 participants in the elementary level while 35 for the high school level, thus a total number of 63 participants were obtained to participate in the semi-structured interview.

\section{Research Instrument}

To gather information on EE practices of public school teachers, the researcher adapted the 18-item questionnaire from Arai, and Shauna Sprules (2001). The questionnaire was modified by the researcher to 10 items to suit to the objectives' proposed investigation. To ensure valid and reliable responses from the participants, validity, and reliability of the questionnaire were established. Experts in the area of EE were asked to validate the revised questionnaire resulting to the validity index of 4.67. To ensure that the modified research instrument is reliable, the questionnaire was pilot tested to the 50 public elementary and high school teachers in the nearby schools division. The obtained reliability coefficient of 0.91 shows that the research instrument was reliable to a very high degree.

On the other hand, to determine the participants' point of views on the practices of public school teachers in the integration of EE in their respective classes, the researcher developed a 10-item questions which validated participants' responses on the questionnaire used for the quantitative part. The 10-item questions focused on the topics was already presented in the method section. The same as with the questionnaires used in the quantitative part of the questionnaire, it was presented to experts for some suggestions and recommendations. Suggestions and recommendations to improve the items were followed and included in the final draft.

\section{Data Analysis}

Frequency and percentage were used to determine the EE practices of public school teachers. However, codes and themes from the responses in the interview of the participants were established to support quantitative results on the different environmental practices of public school teachers.

\section{Results and Discussion}

Responses of the participants revealed that majority of them integrated EE in their lesson, as reflected by the frequency of 571 of the 743 participants. Only a small percent responded that they did not incorporate EE in the lesson $(1.9 \%)$. Others replied that they sometimes integrated EE in their lessons. It is evident from most researches conducted on EE that they were integrated in the lessons and classroom activities. For example, New Zealand environmental education research has shown that most teachers have been teaching and integrating EE for five years or less while others have said they have been teaching and integrating EE for as long as they are teachers (Bolstad, et al., 2004).

The result showed conformity with Section 3 of the Republic Act No. 9512 stating that the DepEd, the Higher Education Commission (CHED), the Department of Social Welfare and Development (DSWD), the Technical Education and Skills Development Authority (TESDA), The Department of Science and Technology (DOST) and other relevant agencies shall, in coordination with the Department of Environment and Natural Resources (DENR), integrate EE into their school curricula at all levels; public or private, including daycare, pre-school, non-formal, technical, vocational, aboriginal education and youth programs (Department of Environment and Natural Resources, 2016).

It is very clear from section 3 of R.A No. 9512 that the state is very concerned with the status of our environment today. One-way to propagate environmental knowledge, attitudes, and awareness, which will all lead to go EE practices is to include or integrate $\mathrm{EE}$ in the curriculum in all levels. This developing environmental knowledge and awareness should start when a child starts learning at home. The home as what considered by everybody as the first school should informally introduce the idea of the environment and how to take good care of it. It is the means by which the community can help minimize the environmental problems we are facing today. 
Table 1. Integration of Environmental Education in the Lesson

\begin{tabular}{ccc}
\hline Responses & $f$ & $\%$ \\
\hline Yes & 571 & 76.9 \\
No & 14 & 1.9 \\
Sometimes & 158 & 21.3 \\
Total & $\mathbf{7 4 3}$ & $\mathbf{1 0 0 . 0}$ \\
\hline
\end{tabular}

Table 2 shows the integration of EE in different subject areas. This is a multiple-response item showing a large percent of integration to subjects such as science followed by social studies and values education. The data from the table reflects that EE was also integrated in subjects such as MAPEH (music, art, physical education, and health), mathematics, and in English and Filipino. Responses of the selected participants in an interview pointed out that there are many topics in science, social studies, and even in values education where EE is possible for integration. In a study on Learning for Sustainable Development: Integrating EE in Tanzania's Curriculum of Ordinary Secondary Schools, the majority of EE skills are delivered primarily through geography and some in biology. This result also illustrates findings where teachers ' responses to EE inclusion in the lesson were mostly on social studies and sciences (Mwendwa, 2017).

On the other hand, EE is mostly taught in science subjects in Thailand, but is some other subject areas, it is also integrated. The researcher in this regard believes this can also be done in the Philippine educational system where EE has possibilities for integration in some other subject areas as shown in the participants' responses in Table 2. Likewise, Kanene (2016) contends that EE implementation can still be done in some other subject areas. His finding indicated that EE is integrated in the secondary school level of teaching in Botswana. However, Johnson (2005) and Palmer (1998) argued that integration of EE into different subjects creates a number of limitations and challenges to the education system. It is also argued that when EE is integrated into the content of other subjects, learners fail to develop a clear understanding of what different disciplines or forms of knowledge contribute to the understanding of an environmental topic (Kadji, 2002).

Resolving these conflicting ideas of the implementation of EE in some other subject areas as pointed out by findings and voices from some authorities in education is to suggest that teachers teaching different subjects areas aside from those mentioned have to identify topics only where integration is possible. Mwendwa in her statement expresses that the integration of EE into an existing subjects many not be accorded weight in all subjects. Let us not force integration of EE in subject areas where it is not fitted but to look for some means integrating $\mathrm{EE}$ in some topics of the subject area.

Table 2. Integration of Environmental Education in the Different Subject Areas

\begin{tabular}{lcc}
\hline Responses & $f$ & \% \\
\hline Social Studies & 571 & 76.9 \\
Science & 643 & 86.5 \\
Values Education & 438 & 59.0 \\
Mathematics & 423 & 56.9 \\
English & 392 & 52.8 \\
Filipino & 268 & 36.1 \\
MAPEH & 345 & 46.4 \\
\hline
\end{tabular}

When asked, "how often do they integrate EE in their lessons?" responses of the participants indicate that majority of them integrate EE weekly. Others are doing it daily. However, some teachers do not integrate EE, but only to a very small percentage $(0.8 \%)$. One participant stated during the interview that "my daily integration of EE is not purely on the lessons or during my class discussion, sometimes my integration focus on outside activities like assigning them tasks such as watering the plants and cleaning the surrounding. They are also encouraged to pick up pieces of papers and plastics in the surroundings, which I think is EE integration in the practical sense". Another participant said, "sometimes I do integration of EE not in the classroom but, I let them do research of the different environmental issues where they should write their reactions and discuss issues the classroom." Teachers believed that learning is not only confined to the four walls of the classroom. Teaching the learners EE in a practical sense would help them develop love for their environment. As stated by Emmons (2016) non-formal education or outdoor education provides opportunities for students to learn outside of the classroom. It is something that happens away from the classroom and this usually happens in natural and physical science related fields, including environmental science and studies. Outdoor education improves students social development and leisure skills (Knapp, 2000; Larsen, Walsh, Almond \& Meyers, 2017). 
In this regard, EE can take place outside as well as inside classrooms and take local as well as global perspectives, but the focus is usually on studying an issue such as water, air, and soil pollution; solid waste and toxic disposal; urban sprawl and population; deforestation; endangered plants and animals; or drought and flooding, especially at upper grade levels (Knapp, 200). Emmons (2016) also contends that it is also important to consider other ways to teach about the environment. Smith (2001) expressed that elementary education is generally taught in social studies and sciences at the upper grades. At elementary levels activities usually span more of the academic curriculum and also incorporate social and recreational objectives leading to teamwork, cooperative and service learning, citizenship skills, and lifelong outdoor pastimes. It can be inferred from the responses that the teachers' manner of integrating EE are propagating EE in their classes and even outside of the classroom. They believed that environmental issues plaguing us today should be addressed. Global warming, for instance, and climate change are two of the most critical issues which the global community is experiencing and need to be given proper attention. As expressed by Muppudathi in UNESCO, "today, we are faced with a major threat called Global Warming. The climate of various places on the Earth is going through a major change. The heat level is rising with every passing day. One of the major factors that contributed to this impending disaster is pollution, which is essentially human-made. All the smoke from the factories and cars are raising the pollution level. The wastes from factories which are being dumped in the rivers are slowly depleting the life of animal that thrive in the water".

Table 3. How often is Environmental Education Integrated in the Lesson?

\begin{tabular}{lcc}
\hline Responses & $f$ & \% \\
\hline Daily & 225 & 30.3 \\
Weekly & 346 & 46.6 \\
Biweekly & 73 & 9.8 \\
Monthly & 93 & 12.5 \\
Never & 6 & 0.8 \\
Total & 743 & 100.0 \\
\hline
\end{tabular}

Considering activities used to help students learn about the environment, Table 4 shows that EE was integrated in the different classes using different techniques. One technique frequently used to help students learn about the environment was fund-raising to raise money for the conservation of the environment. Likewise, they also use nature videos, invite speakers to talk on environmental issues, and field trips that encourage planting trees, recycling, greening schoolyards, etc. They believed that these techniques of integrating EE are more effective in helping students learn about the environment. Besides, they thought that these techniques were easy to manage. This is more visible and workable than the rest of the techniques. Using multimedia or technology according to Emmons (2016) can be an excellent tool to teach about the environment. On the other hand, Smith and Fedesco (2020) citing Dewey's (1897) philosophy "learning experiences outside the classroom or experiential learning" expressed that there are many ways to make learning extended outside the classroom: among them was fieldtrips. Fieldtrips can develop social and personal skills, develop observation and perception skills, add relevance and meaning to learning, provide first-hand real-world experiences, and enhance intrinsic motivation and interest in the subject (Behrendt \& Franklin, 2014; Larsen et al., 2017; Tal \& Morag, 2009).

Schweizer and Kelly (2005), however, shared that students are learning more when they can do it on their own, and this is particularly true for topics that are possible turn-offs for students. Environmental issues are used to teach strategies such as using regional examples, collecting field data, using role-playing or discussions, and engaging in environmental projects. In other words, active learning techniques such as these should be used in teaching or integrating EE in the lessons. These techniques are appropriate to be used in the classroom because this may be an eye-opener for the pupils and students to realize that our environment is already threatened by environmental problems threatening the fauna and the flora.

Table 4. Activities Used to Help Students Learn About the Environment

\begin{tabular}{lcl}
\hline \multicolumn{1}{c}{ Activities } & $f$ & \multicolumn{1}{c}{$\%$} \\
\hline Lecturing in the classroom & 511 & 68.8 (Never) \\
Showing nature videos & 278 & 37.4 (Occasional) \\
Hands-on learning in the outdoors & 343 & 46.2 (Occasional) \\
Exploring a local issue. & 273 & 36.7 (Occasional) \\
Using role-playing & 241 & 32.4 (Occasional) \\
Inviting guest speaker/s & 267 & 35.9 (Often) \\
Field trips & 311 & 41.9 (Often) \\
Practical conservation & 197 & 26.5 (Occasional) \\
Fund-raising & 336 & 45.2 (Frequent) \\
Using an interdisciplinary approach & 241 & 32.4 (Occasional) \\
\hline
\end{tabular}


In terms of discussing the different perspectives on environmental issues when integrating EE in the lessons, Table 5 reveals that only 118 of the 743 public school teachers replied, "yes." They discussed the different perspectives on environmental issues. In other words, a large percentage of them did not discuss the different views of the environmental problems when integrating EE in the lesson. In an interview conducted, responses of the participants indicated that they have difficulties discussing the different perspectives of environmental issues. One participant said, "our task is only to integrate EE in the lesson, and discussing the different perspectives of EE is difficult for me. I don't have enough background in integrating EE. Likewise, I don't have the pedagogy of teaching and integrating EE in my subject area".

Research findings on the teaching of EE showed that despite the fact that EE is integrated in the content of different subjects, teachers did not teach it because they lack knowledge and skills in the teaching of EE (Bolstad, 2004) and few got the opportunity to see how EE is taught (Mtaita, 2005). Although Makundi (2000) supports this argument, she further attributes this situation to the approaches and methodologies used in teaching. She points out that the teaching and learning methods used emphasized knowledge and awareness-raising only. Similarly, Spiropoulou et al. (2007) argue that the implementation of EE has been less effective due to the traditional teaching approaches, inflexible curricula, a lot of content to be learnt and insufficient time for an indepth approach to the study of environmental matters. It can be said that it is true that the traditional approach to teaching which is based on transmission of knowledge cannot help learners develop the skills and action competence necessary for taking action on the environment. Learners will be able to develop skills and action competencies if they are actively involved in hands on activities in the environment.

This response is reflective of the fact that EE was not given proper attention before and even until now. Teachers are committed to develop the cognitive ability of young minds with less importance in developing the affective aspects of the students. Public school teachers believed that they have already mastery of the subject matter because they have been teaching the subject for many years. Giving them activities to master, like integrating $\mathrm{EE}$ in their lesson, is quite difficult to them. Besides teaching the subject would be more difficult to them because according to them they don't have any knowledge, skills, and techniques in dealing with integration. Responses of the public school teachers imply that they need to be trained in doing integration. They should have enough background and knowledge of how to integrate EE in the lesson.

\begin{tabular}{ccc}
\multicolumn{3}{l}{ Table 5. Discussion of the Different Perspectives on Environmental Issues } \\
\hline Responses & $f$ & $\mathbf{\%}$ \\
\hline Yes & 118 & 15.9 \\
No & 625 & 84.1 \\
Total & $\mathbf{7 4 3}$ & $\mathbf{1 0 0 . 0}$ \\
\hline
\end{tabular}

When integrating EE in the lesson, public school teachers did not encourage students to form their views and ideas, as shown by 691 of the 743 participants who replied "no". Only a few of them helped students to develop their perspectives. On the other hand, a very small percent sometimes encouraged students to form their opinions and ideas. In conjunction with teachers' previous responses, a substantial percentage of them did not encourage students' views and ideas during the discussion of the different environmental activities. However, as cited by King (https://www.ideaedu.org), understanding other viewpoints are improved by direct interaction with those with a different perspective as long as the atmosphere is healthy and well-crafted. This means that they were hesitant to develop environmental awareness and consciousness among their students through lecturediscussion in their lesson. As quoted by one participant, "I have desire to develop students environmental awareess and consciousness during our discussion. However, the little knowledge and skills I have of integration and of the environmental topics and issues, I fell hesitant to asks questions which will encourage them to form their views and ideas, but there is still willingness in me to develop their environmental awareness and consciousness".

Kimaryo (2011) cited barriers in the integration of EE and some of she cited were lack of teaching and learning resources, time and large class. Furthermore, she expressed that the role of teachers in the implementation of EE in developing an environmentally literate citizenry is of great significance. The responsibility of the government in developing a curriculum with clear goals and content, developing teachers' capacity in the teaching of EE and provision of teaching and learning materials need to be undertaken seriously by the government in educational plans and progress. Similarly, Van Petegen et al. (2007) found that teachers in Zimbabwe acknowledged the importance of EE, but spent very little time in teaching it, because they found it difficult to relate the content of their subjects to EE. Another contributing factor is that, although EE was seen as urgent by some governments such as in Hong Kong and the United Kingdom, it was given low status by not making it compulsory and crosscurricula, and every school could teach EE at its own discretion (Chi-chung Ko \& Chi-kin Lee, 2003). 
Table 6. Encouraging Students to Form their Views and Ideas when Teaching Environmental Education

\begin{tabular}{ccc}
\hline Responses & $f$ & \% \\
\hline Yes & 46 & 6.2 \\
No & 691 & 93.0 \\
Sometimes & 6 & 0.8 \\
Total & $\mathbf{7 4 3}$ & $\mathbf{1 0 0 . 0}$ \\
\hline
\end{tabular}

Table 7 shows the integration of EE based on the curriculum and the teacher's initiative. Responses of the participants reveal that 312 or $42.0 \%$ of the participants integrated environmental education mostly on their initiative. Others responded that about half from the curriculum was integrated into the teaching of EE in the lesson, while only a few of them (11 of 743) integrated EE $100 \%$ on their initiative.

In this regard, EE was integrated into the different lessons and subject areas but was not properly implemented. Although there are subjects in the curriculum where integration has taken place, however, it is only limited. One participant quoted that "when I integrate EE in my class, it is based purely on my initiative. Although we are provided with a course guide, integration was only limited to a few topics and subject areas". These responses from the participants showed that teachers were willing to integrate EE even if it is not mandated because they believed that there is a need for doing such.

Table 7. Environmental Education Integration from the Curriculum and Teacher's Initiatives

\begin{tabular}{lcc}
\hline Responses & $f$ & \% \\
\hline 100\% from the curriculum & 35 & 4.7 \\
Mostly from curriculum & 137 & 18.4 \\
About half from the curriculum & 248 & 33.4 \\
Mostly own initiative & 312 & 42.0 \\
100\% own initiative & 11 & 1.5 \\
Total & $\mathbf{7 4 3}$ & $\mathbf{1 0 0 . 0}$ \\
\hline
\end{tabular}

Table 8 disclosed that 438 of the 743 participants replied that the integration of EE should be in all subjects. Only a few of them responded that it should be integrated with a few subjects, while only a countable replied that it should not be integrated with any subjects. In this regard, participants were positive in their responses that the integration of EE should be done in all subject areas. They believed that the integration of EE is essential nowadays. The scenarios right now are indicative of the fact that EE should be integrated in the classroom. They said that "we need our students to be aware and should practice stewardship towards the environment." Some teachers responded that integration should be done in some other subjects because they believed that it is very hard for them to integrate EE in other subject areas. As quoted by the participant during the conduct of the interview, "I believe that EE is very important to consider nowadays. However, I find it hard in most of my subject matter to integrate EE. Although I do it but in rare instances." Responses of the participants were confirmed by Mwendwa (2017). She stated that in Tanzania, the country, through the ministry of education, formulated $\mathrm{EE}$ courses and incorporated them officially in secondary school curriculum at all levels as integrated subjects, not stand alone subjects.

\begin{tabular}{lcc} 
Table 8. Classroom Integration of Environmental Education in the Subject Areas \\
\hline Responses & $f$ & $\mathbf{\%}$ \\
Integration should in all subjects & 438 & 59.0 \\
Integration should be in most subjects & 252 & 33.9 \\
Integration should be in a few subjects & 44 & 5.9 \\
Integration should not be in any subjects & 9 & 1.2 \\
Total & $\mathbf{7 4 3}$ & $\mathbf{1 0 0 . 0}$ \\
\hline
\end{tabular}

As reflected in the previous table, there are problems in the integration of EE in public schools. This table revealed that one of the major issues was on the implementation of R.A 9512: An Act to Promote Environmental Awareness through EE. Participants also identified training for teachers as another obstacle. Other obstacles identified were the quality of curriculum materials, accessibility to natural areas, field trips and equipment, and support from administration.

It cannot be denied that there are always problems in the implementation of any programs in the school. The integration of EE posed problems among our teachers, school administrators, and other stakeholders. Challenges or obstacles experienced were on the implementation of R.A 9512, quality of materials in the curriculum, and training for teachers. Although, it was found that teachers were aware of R.A 9512, however, they were not so 
familiar with the content and guidelines of this act. However, they believed this act is essential and useful, as in a response by one participant "this will guide the Department of Education to require us, teachers, to religiously incorporate environmental education in our classes." Another participant also said that "I believe that this republic act will bring awareness to the schools and do practice what was being enunciated in this republic act. Environmental awareness and practices incorporated during the class discussion will help students to be advocates of caring for the environment". Although considered as an obstacle, however, they were positive towards the implementation of this act.

Another obstacle participants pointed out was on the quality of curriculum materials. One participant said that instructional materials has always been a problem in the school not only here in the Philippines, but also in some other parts of the globe. Pointing out to the integration of EE is another problem which the Department of Education needs to address. Teachers are willing to integrate EE in their classes. However, instructional materials or resources are not fully available. Books are present, but only a few topics were used for the integration of EE. One participant quoted that "sometimes it is hard for us to integrate EE because we don't have any instructional materials to use. If we want to integrate, we do it in our own". This response reflects that school authorities should look for possible solutions to this problem.

In Botswana, the adoption of integrated approaches to environmental education in schools that lack resources to support integration (for example, transportation for experiential outdoor activities, adequate time to teach environmental content, and trained teachers to incorporate environmental concerns and issues across the curriculum) was done compulsory. Teachers in Botswana are hardly equipped with sufficient resources to help them integrate environmental content into their curriculum (Valempini, 2016). Moreover, Botswana teachers are rarely equipped with enough learning resources to promote the incorporation of environmental material into the curriculum Kethoilwe (2003).

These responses are not only happening in Botswana but also worldwide. Here in the Philippines, we are starting to integrate EE in the Curriculum. The Department of Education is issuing policies and guidelines on how EE should be integrated in the classroom. As an answer to this problem, the Philippine Normal University Visayas, as an Environment and Green Technology Education (EGTE) hub, is promoting EE in the classroom by helping teachers in the field through their program of offering diploma courses in EE and integrating EE in the Outcome-Based Teacher Education Curriculum.

Training for teachers is another issue of concern in the integration of EE in different classrooms. Since EE was not included in the curriculum before, the Department of Education has no worries for training teachers in that regard. But today, environmental protection and many other environmental issues are always talked not only in the community but in the school because the community believes that EE will be minimized. Along this line, in almost all parts of the globe, in Botswana for instance there are educational constraints in the efforts of integrating EE. In-service and pre-service professional development of teachers is inadequate (Kethoilwe, 2003; Mosothwane, 2002). Braus (1993) as cited in Lane (2006) directly states that "it is difficult to infuse EE and requires extensive teacher training and effort [and that it] often relies on motivated teachers for efforts to succeed."

Table 9. Identified Obstacles in the Integration of Environmental Education in the Public School

\begin{tabular}{lcc}
\hline Responses & $\boldsymbol{f}$ & $\boldsymbol{\%}$ \\
\hline Quality of curriculum materials & 366 & 71.3 \\
Field trip and equipment & 176 & 34.3 \\
Training for teachers & 330 & 64.3 \\
Implementation of R.A 9512 & 384 & 74.9 \\
Accessibility to natural areas & 255 & 49.7 \\
Support from administration & 32 & 6.2 \\
\hline
\end{tabular}

Considering teacher's involvement in the different environmental activities, Table 10 reflects that a substantial percent $(97.8 \%)$ of them are involved in promoting an environmentally conscious lifestyle. The data also shows that 621 of the 743 respondents were reading on environmental issues. Likewise, 554 out of 743 of them set up membership in an association that is actively involved in environmental issues. However, they have the least involvement in the development of curricula in EE.

It is obvious from teachers' responses that they involve themselves in different environmental activities. A very large percentage of them are participating in environmental consciousness, which means that they advocated 
love for the environment. As stated by the majority of the teachers, they avoid using plastics at home and in school. They are using biodegradable materials for use.

Another teacher's involvement worth noticing is reading about environmental issues and membership in an organization that is actively involved in environmental issues. Teachers believe that reading about environmental issues will help them in becoming aware of what is happening in the global environment right now. Their readings will lead them to teach EE rigorously in their respective classes. As stated by a participant in an interview, "I want to read what was happening in our mother earth. I want to read innovative strategies on how we help promote awareness and consciousness among members of the community and, most especially, to our students". These actions of teachers are worth emulating. Having love and concern for the environment is the need of the time. We cannot avoid natural disasters, but we can minimize the damage that it will bring to us if we do love and care for our environment.

On the other hand, other teachers are members of the organization that are actively involved in the different environmental issues. As reflected by one participant, "this is better than not because aside from doing nothing at least I can do help promote consciousness among other members of the community. Involving myself in this activity strengthens my will to spread the love for Mother Earth". Another participant supported by saying, "It's a nice feeling when you influence others to do what you are doing in protecting our environment. It is better late than never, by propagating love to our environment for me is a willful act". These acts among our teachers is commendable. Involving different environmental activities is a good indication that people have concerns about the environment, especially when teachers are leading. Thus, it is time and proper that EE should be integrated in preschool, elementary, high school, tertiary, and even in the graduate school level. The Philippine Normal University Visayas as an Environment and Green Technology Education (EGTE) hub is doing this. In the undergraduate and graduate programs of the university, electives that promote environmental awareness and consciousness are included in the curriculum. This is one way of propagating environmental knowledge, awareness, and practices.

Table 10. Teachers Involvement in the Different Environmental Activities

\begin{tabular}{lcc}
\hline Responses & $f$ & $\boldsymbol{\%}$ \\
\hline $\begin{array}{l}\text { Membership in an organization actively involved in } \\
\text { environmental issues }\end{array}$ & 554 & 74.6 \\
$\begin{array}{l}\text { Attending public meetings regarding environmental } \\
\text { issues }\end{array}$ & 296 & 39.8 \\
$\begin{array}{l}\text { Writing letters, e.g., writing a letter to the government } \\
\text { discussing opinion on endangered species legislation }\end{array}$ & 344 & 46.3 \\
$\begin{array}{l}\text { Curriculum development in environmental education } \\
\text { Outdoor recreation, e.g., hiking, etc. }\end{array}$ & 215 & 28.9 \\
$\begin{array}{l}\text { Environmentally conscious lifestyle } \\
\text { Read about environmental issues }\end{array}$ & 351 & 47.2 \\
\end{tabular}

\section{Conclusion}

One of the most critical issues that the government needs to address is EE. All inhabitants are experiencing environmental stress brought about by environmental problems on toxic wastes, pollution, global warming, loss of ozone, climate change, extinction of species, inadequate control of waste, etc. Due to the alarming state of our planet earth, there is a need for us to propagate our love and concern for the environment, and this can only be done by strengthening EE in the curriculum at all levels. In the Philippine context, EE is integrated in the lesson, especially in science, social studies, and values education. EE is also implemented in some other areas but only to a limited extent.

In the research, majority is integrating EE weekly while others are doing it monthly and only a few are doing it daily or regularly. This means that there is no clear policies and guidelines on the number of hours or even the manner of integration with reference to time. Furthermore, to help students learn about environmental issues, lecture-discussion is commonly done; however, other activities are also used. This a clear indication that there are still possibilities of integrating EE in almost all of the subject areas. But in the lecture-discussion, no evidence of discussing the different perspectives of EE is considered. Likewise, students are not encouraged to form their views when $\mathrm{EE}$ is integrated with the classroom. 
Further, the integration of EE is mostly from the teacher's initiative. However, they believe that integration could be done in all subject areas. On the other hand, the implementation of EE R.A 9512, instructional materials and teacher training are considered obstacles in the integration of EE.

\section{Recommendations}

Along with these findings and conclusions, EE should be integrated in public elementary schools and in almost all of the subject areas. Integration should not only be as the need arises during the discussion but should be reflected in the lesson plan and a particular subject matter. Likewise, the integration of EE should be concretely done. In this contention, school administrators and teachers should identify subject matter from the competencies where EE integration is possible. The integration of EE, therefore, should be included in the competencies, and this should be reflected in the different instructional materials like books and other supplementary materials.

Consequently, integration as mentioned and are being studied in this research is not just an easy task, problems, and barriers were identified. Among them are instructional materials, training for teachers, and the implementation of R.A 9512. Along with these problems and barriers of integration, it is a need that teachers should be trained in the process of integration. Training and seminars on how to incorporate EE into the lessons should be provided to them.

Lastly, this study recommends that the integration of EE in the different subject areas and the classroom should be strengthened. Our environment is already experiencing environmental stress brought by the different environmental problems. We cannot deny the fact that these are the results of global climate change, global warming, depletion of ozone, pollution, extinction of species, and unsuitable waste management that we believe to be caused by us. Let's talk about this situation and use our school as a tool to inspire us to be our environment's steward.

\section{Acknowledgements}

The author would like to express his appreciation to the people who have contributed to the success of this research paper. Special thanks to my family for the unending support bestowed upon me; public elementary and secondary teachers in the Schools Division of Cadiz City who are my participants of the study; my co-teachers who have supported me during the conduct of my research instrument; Philippine Normal University Visayas for the opportunity and support; and above all to God Almighty, for without Him, we are nothing.

\section{References}

Arai, E. \& Sprules, S. (2001). The Status of Environmental Education in British Columbia Public Schools: Grades 6, 7, and 8 in the Vancouver School District as a Case Study. Undergraduate Honours Thesis, University of British Columbia, Canada, 1-94.

Asano, M. (1991). Environmentally yours by early times. Tokyo: Macmillan

Behrendt, M., \& Franklin, T. (2014). A review of research on school field trips and their value in education. International Journal of Environmental and Science Education,9, 235245. http://doi.org/10.12973/ijese.2014.213a

Bolstad et al., (2004). Environmental education in New Zealand schools: Research into current practice and future possibilities. NZCER and University of Waikato, for the Ministry of Education

Brown, L. (2003). Priorities for environmental education: What supports do secondary school teachers need to implement education for the environment? Master's thesis: Griffith University.

Chi-chung Ko, A., \& Chi-kin Lee, J. (2003). Teachers Perceptions of Teaching Environmental Issues within the Science Curriculum: A Hong Kong Perspective. Journal of Science Education and Technology, 12(3), $187-204$.

Creswell, J. W. (2008). Educational Research. Planning, Conducting and Evaluating Quantitative and Qualitative Research (3rd edition). Upper Saddle River, New Jersey: .Pearson Education, Inc.

Department of Environment and Natural Resources, (2016). June is Environment Month. Retrieved on March 13, 2017 from https://goo.gl/dVReE6

Dewey, J. (1897). My pedagogic creed. New York: E. L. Kellogg \& Co. 
Emmons, N. (2016). Teaching environmental education in the classroom. Retrieved from http://www.huffing tonpost.com/nichlas-emmons/teaching-environmental-ed_b..

Fien, J \& Trainer, T. (1993). Education for sustainability. In Environmental education: A pathway to sustainability. Edited by Fien, J.(1993). Geelong, Victoria: Deakin University Press.

Gay, L.R., \& Airasian, P. (2003). Educational research: competencies for analysis and application (7th edition). New Jersey: Merrill Prentice Hall.

Huckle, J. (1991). Education for sustainability: Assessing pathways to the future. Australian Journal of Environmental Education. 7: pp. 43 - 59.

Jambiya, G. (2003). A baseline study of six villages in Musoma in Mara Region for the WWF Eastern Africa region.

Johnson-Pynn, J. S., \& Johnson, L. R. (2005). Success and challenges in East African Conservation Education. Journal of Environmental Education, 36 (2), 25 - 39.

Kadji C. (2002). Evaluation of whole school environmental education, Kansas association for conservation and environmental education, Available at: www.kacee.org (Accessed April 2019).

Kanene, M. (2016). The impact of environmental education on the environmental perceptions/attitudes of students in selected secondary school in Botswana. European Journal of Alternative Education Studies. Volume 1, Issue 2.

Ketlhoilwe, M. (2003). Environmental education policy implementation in Botswana: The role of secondary education officers and school heads. Southern African Journal of Environmental Education, 20, 75 - 84.

Kimaryo, L.A. (2011). Integrating environmental education in primary school education in Tanzania: teachers' perceptions and teaching practices. Published Thesis, Åbo Akademi University Press, 2011. Diss.: Åbo Akademi University.

Knapp, C.E. (2000). Learning from an Out-door Education Hero: Personal Reflections about L. B. Sharp." Taproot 12:7-11.

Lane, J.F. (2006). Environmental education implementation in Wisconsin: conceptualization and practices (Unpublished doctoral dissertation). University of Wisconsin-Madison

Larsen, Carl \& Walsh, C. \& Almond, N. \& Myers, C.. (2016). The "real value" of field trips in the early weeks of higher education: the student perspective. Educational Studies. 1-12. 10.1080/03055698.2016.1245604.

Lindhe, V. (1999). Greening Education, Prospects and Conditions in Tanzania. Doctoral Thesis, Uppsala University.

Limusnero, D.P. (2016). Environmental awareness, knowledge, and practices of grade six pupils:bases for materials development in teaching science. Unpublished Thesis, Philippine Normal University Visayas, Cadiz City, Negros Occidental.

Makundi, E, (2000). The Impact of the integrated social skills among Primary School learners in Mainland Tanzania. Unpublished Masters Dissertation, Dar-es-Salaam: Faculty of Education, University of Dar-esSalaam.

Marpa, E. P. \& Juele, M. H. R. (2016). Environmental Awareness and Practices among High School Students: Basis for Disaster Preparedness Program. Applied Mechanics and Materials, 848, 240-243.

Marques, R., \& Xavier, C. R. (2020). The Challenges and Difficulties of Teachers in the Insertion and Practice of Environmental Education in the School Curriculum. International Journal on Social and Education Sciences, 2(1), 49-56.

McLean, T. (2003). Environmental education in Otago primary schools. Education for the environment? set: Research information for teachers, 1, $4-9$.

Memije-Cruz, L. (2010). Air pollution, global warming, and the greenhouse effect. http://liwaymemije cruz.blogspot.com/2010/03/air-pollution-global-warming-and.html

Moses, J. (2004). Is it Green Enough? Evaluating Environmental Education Programmes Effectively. In U. Azeiterio, F. Goncalves, W. Leal Filho, F. Morgado \& M. Pereira (Eds.), World Trends in Environmental Education. Bern: Peter Lang.

Mosothwane, M. (2002). Pre-service teachers' conceptions of environmental education. Research in Education, $68,26-40$.

Mtaita, U. Y. (2005). The potentials and opportunities of environmental education in Tanzanian secondary schools, using New Zealand schools as an example. A directed study submitted in partial fulfillment of the requirements of the degree postgraduate diploma in science education. CSTER: Waikato University.

Mwendwa, B. (2017). Learning for Sustainable Development: Integrating EnvironmentalEducation in the Curriculum of Ordinary Secondary Schools in Tanzania. Journal of Sustainability Education. Vol. 12, February 2017

Palmer, J. (1998). Environmental Education in the 21st Century: Theory, practice, Progress and Promise. London: Routledge. 
Peter, K. and Cheruto, K. (2013). The Need to Integrate Themes of Environmental Education in the School Curriculum in Kenya. International Journal of Academic Research in Progressive Education and Development January 2013, Vol. 2, No. 1

Puri K., \& Joshi R. (2017). Ecoclubs: an effective tool to educate students on biodiversity conservation. Biodiversity International Journal, 1(5):50-52. DOI: 10.15406/bij.2017.01.00028

Rogan, D.V. and Nebrida, E.A (2019). Environmental Awareness and Practices of Science Students: Input for Ecological Management Plan. International Electronic Journal of Environmental Education Vol.9, Issue 2, 2019, 106-119

Rogayan, D.V. Jr. (2019). I Heart Nature: Perspectives of University Students on Environmental Stewardship. International Journal of Engineering, Science, and Technology, 1(1), 10-16.

Schweizer, D. and Kelly, G. (2005). An investigation of student engagement in a global warming debate. Journal of Geoscience Education v 53, n 1, p. 75-84

Smith, G.A. (2001. Defusing environmental education: an evaluation of the critique of the environmental education movement." Clearing: Environmental Education Resources for Teachers 108 (winter):22-28.

Smith, G. \& Fedesco, H. (2020). Teaching in the classroom. Retrieved from https://cft.vanderbilt.edu/guidessub-pages/teaching-outside-the-classroom/ on April 16, 2020.

Spiropoulou, D., Antonakaki, T., Kontaxaki, S., \& Bouras, S. (2007). Primary Teachers' Literacy and Attitudes on Education for Sustainable development. Journal of Science Education Technology, 16, 443 - 450.

Steve, J. \& Cooper,T. N.(1985). Instructional design in technical areas. Camberwell, Australia: ACER Press.

Summers, M., Corney, G., \& Childs, A. (2003). Teaching Sustainable Development in Primary Schools: an empirical study of issues for teachers. Environmental Education Research, 9 (3), 327 - 346.

Tal, T., \& Morag, O. (2009). Reflective Practice as a Means for Preparing to Teach Outdoors in an Ecological Garden. Journal of Science Teacher Education, 20(3), 245-262.

Thathong, K. (2019). An integration of teaching and learning activities on environmental education in the subjects. Research in Higher Education Journal

Thomas, I. (2004). Sustainability in tertiary curricula. What is stopping it happening? International Journal of Sustainability in Higher Education, 5 (1), 33 - 47.

UNESCO-UNEP (1994). Population: Working for an equitable, sustainable development in harmony with the environment. Connect. 19(4): pp. 1-2.

UNESCO-UNEP (1994). Population: Working for an equitable, sustainable development in harmony with the environment. Connect. 19(4): pp. 1-2.

URT, (2009). National education and environment communication strategy. 2nd ed. Dar es Salaam: National Environment Management Council.

Van Petegem, P., Blieck, A., \& Van Ongevalle, J. (2007). Conceptions and awareness concerning environmental education: a Zimbambean case study in three secondary teacher education colleges. Environmental Education Research, 13 (3), 287 - 306.

Velempini, K. M. (2016). The Integration of Environmental Education in the Secondary School Curriculum: A Case Study of a 10th Grade Junior Secondary School Curriculum in the Okavango Delta, Botswana. Unpublished Dissertation, The Patton College of Education of Ohio University, Ohio City. 